\title{
FEEDING BEHAVIOUR OF THE MUSSEL, MYTILUS EDULIS: RESPONSES TO VARIATIONS IN QUANTITY AND ORGANIC CONTENT OF THE SESTON
}

\author{
B.L. BAYNE*, J.I.P. IGLESIAS ${ }^{+}$, A.J.S. HAWKINS*, E. NAVARRO ${ }^{+}$, \\ M. HERAL ${ }^{\ddagger}$ AND J.M. DESLOUS-PAOLI ${ }^{\ddagger}$
}

*Plymouth Marine Laboratory, The Hoe, Plymouth, PL1 3DH. 'Departomento de Biologia Animal y Genetica, Universidad del Pais Vasco, A partado 644, 48080 Bilbao, Spain. IIFREMER, BP 133, 17390 La Tremblade, France

\begin{abstract}
Mussels were fed four concentrations of seston (between 0.99 and $10.3 \mathrm{mg}$ total seston $\mathrm{l}^{-1}$ ), comprising three levels of organic content $(71 \cdot 9,63.6$ and $40.8 \%)$, made up from natural silt and two species of cultured phytoplankton. Two of the seston concentrations were below, and two above, the threshold at which pseudofaeces were produced. Measurements of physiological traits (filtration rates, pseudofaeces production, selection efficiency, absorption efficiency, absorption rates and rates of oxygen consumption) were made after 2 days and, for two of the seston concentrations, also after 12 days. When fed at a high concentration of seston of low organic content, the mussels increased their filtration rate, rejected a higher proportion of filtered material as pseudofaeces, and increased the efficiency with which filtered matter of higher organic content was selected for ingestion; this resulted in a constancy of the relationship between ingestion rate and the concentration of particulate organic matter, regardless of differences in seston organic content. Between 2 and $12 \mathrm{~d}$, the mussels increased absorption rates for organics, primarily by increasing absorption efficiency, both for total organics and for the carbohydrate component of the diet. We suggest that these responses to changes in the food environment comprise physiological adjustments which result in higher net rates of absorption than would be predicted from considerations only of the organic/inorganic ratio of the suspended particles and assumptions of a non-compensating feeding behaviour.
\end{abstract}

\section{INTRODUCTION}

Feeding behaviour in suspension-feeding bivalve molluscs is responsive to many factors, both biotic and abiotic. Recently, attention has turned from such factors as sizeand temperature-dependence (reviews by Bayne \& Newell, 1983; Griffiths \& Griffiths, 1987) to the study of the effects of changes in the quantity and the quality of the seston which comprises the available food (Widdows et al.,1979; Kiørboe \& Møhlenberg, 1981; Newell \& Jordan, 1983; Bricelj \& Malouf, 1984; Shumway et al., 1985; Bayne et al., 1987, 1989; Lucas et al., 1987; Newell et al., 1989; Fielding \& Davis, 1989; Stenton-Dozey \& Brown, 1992; Navarro et al., 1991, 1992; Iglesias et al., 1992). Such studies are predicated on an appreciation of the diverse nature of available food within natural environments, comprising a variable mixture of algal cells, detritus and silt. 
There are two rather different ways of viewing the feeding processes of bivalves. Jørgensen et al. (1988) and Jørgensen (1990) have suggested that responses to environmental changes are determined solely by the physical properties of the ciliary mechanisms of pumping and filtration; physiological processes of control, regulation and modulation of feeding behaviour are denied or ignored. On the other hand, the innate homoeostatic properties of physiological systems may be recognized and emphasis given to the means by which bivalves vary components of feeding behaviour so as to maximize net energy gains in response to variations in the food environment (Bayne et al., 1987, 1988, 1989; Hawkins \& Bayne, 1992; Willows, 1992). We consider that the experimental evidence is in support of the existence of physiological compensations (or acclimations) which serve to maintain a relative constancy of rate of absorption of organic matter from available food in mussels subjected to time-varying ration of different quantities and organic content. This paper describes experiments designed to explore these processes in more detail. We define 'physiological compensations' as modifications to physiological processes, in terms of altered rates and efficiencies, tha' result in an enhancement of net energy gain over values that would pertain were physiological changes not to occur in response to changes in environment (in the specific case, changes in the food environment).

The experiments had four aims: (1) to evaluate the short-term responses of components of feeding behaviour of mussels, Mytilus edulis L., to different levels of seston and particulate organic matter (POM), from well below to significantly above the concentration at which pseudofaeces (i.e. material filtered from suspension but rejected before ingestion) are produced; (2) to test the hypothesis that acclimation of feeding behaviour occurs when mussels are held on a specific diet, acting to increase the net rate of absorption of organic matter; (3) to consider whether acclimation occurs, not just for total organic matter, but also in terms of the basic biochemical components of the diet; (4) to describe the features of feeding behaviour which may contribute to such acclimation.

\section{MATERIAL AND METHODS}

\section{Experimental conditions}

Mussels (Mytilus edulis L.) were collected from Beggars Island in the Lynher Estuary. south-west England, on two dates in 1987, 28 June and 3 July. Mussels were chosen of approximately uniform size (length 4-5 cm); they were scraped clean of encrusting organisms, thoroughly washed in clean sea-water and left overnight before being placed in experimental trays. Mussels collected on 28 June were held under ration conditions A and $D$ (see below) from 29 June, and measurements made $2 \mathrm{~d}$ later; these two conditions were then terminated. Mussels collected on 3 July were held under ration conditions B and $C$ (see below) from 4 July, measurements made $2 \mathrm{~d}$ later and then again after $12 \mathrm{~d}$.

The mussels were held in trays within a system of recirculating sea-water, which was temperature-controlled at $15 \pm 0.5^{\circ} \mathrm{C}$ at a salinity of $32.5 \%$. Each tray held 12 mussels. Water was passed across the mussels at $61 \mathrm{~h}^{-1}$, and the appropriate ration was pumped continuously into the inflow port of each tray from a seston reservoir. The seston in each 
reservoir was vigorously stirred both by a magnetic stirrer and by aeration. Samples taken from trays not containing mussels demonstrated no significant settlement of particles, and an even distribution of food particles throughout the tray.

The experimental conditions were defined in terms of ration quantity (total mass of seston) and the organic content of the seston; we endeavoured to reproduce ration conditions similar to those found in the natural environment (Bayne et al., 1989). The ration consisted of a mixture of silt and the cells of two algal species, Tetraselmis suecica Parke and Phaeodactylum tricornutum Bohlin. Silt was collected from the surface of mudflats adjoining the mussel population in the estuary; in the laboratory it was dried and then ground in a pestle and mortar before sieving through a mesh of $50 \mu \mathrm{m}$. The two algal species were harvested during the logarithmic phase of growth in laboratory cultures which were not axenic. Following daily determination of cell densities in volumetric units $\left(\mathrm{mm}^{3} \mathrm{l}^{-1}\right)$, using a Coulter Electronics ${ }^{\circledR}$ Multisizer, the harvested cultures were mixed in equivalent total cell volumes, and silt then added, according to a predetermined experimental protocol.

This protocol comprised 12 ration conditions (Table 1). Designations A, B, C and D refer to increasing quantities of seston; designations in Roman numerals I, II and III refer to decreasing organic contents, which averaged (means and 95\% confidence limits; samples taken for analysis at various times in the experiments) $71.9 \pm 3.6,63.6 \pm 2.4$ and $40.8 \pm 3.6 \%$ of total seston, respectively. The net result for the experiment as a whole was a range of ration levels, from 0.99 to $10.3 \mathrm{mg}$ total seston $\mathrm{l}^{-1}$, and 0.63 to $5.85 \mathrm{mg} \mathrm{POM} \mathrm{l}^{-1}$. We designate physiological determinations made after $2 \mathrm{~d}$ exposure to these rations as representing the 'acute' response of the mussels; determinations made after $12 \mathrm{~d}$ (Bayne

Table 1. Ration conditions in the experiments. Values are means with $95 \%$ confidence limits, calculated for at least six determinations made over $2 d$ (the '2- $d$ ' conditions) or $12 d$ (the '12- $d$ ' conditions).

\begin{tabular}{|c|c|c|c|c|c|}
\hline $\begin{array}{c}\text { Ration } \\
\text { condition }\end{array}$ & Days & $\begin{array}{l}\text { Total seston: } \\
\quad\left(\mathrm{mg} \mathrm{l}^{-1}\right)\end{array}$ & $\begin{array}{c}\mathrm{POM} \\
\left(\mathrm{mg} \mathrm{l}^{-1}\right)\end{array}$ & $\begin{array}{l}\text { Total seston } \\
\left(\mathrm{mm}^{3} \mathrm{l}^{-1}\right)\end{array}$ & $\begin{array}{c}\text { Quality } \\
\left(\mathrm{mg} \text { POM } \mathrm{mm}^{-3}\right)\end{array}$ \\
\hline $\mathrm{AI}$ & 2 & $1.15 \pm 0.11$ & $0.83 \pm 0.08$ & $1.20 \pm 0.59$ & 0.69 \\
\hline AII & 2 & $0.99 \pm 0.17$ & $0.63 \pm 0.11$ & $1.19 \pm 0.32$ & 0.53 \\
\hline AIII & 2 & $1.72 \pm 0.42$ & $0.70 \pm 0.17$ & $1.10 \pm 0.39$ & 0.64 \\
\hline $\mathrm{BI}$ & 2 & $2.71 \pm 0.72$ & $1.95 \pm 0.52$ & $1.90 \pm 0.69$ & 0.97 \\
\hline $\mathrm{BII}$ & 2 & $3.01 \pm 0.63$ & $1.91 \pm 0.40$ & $1.97 \pm 0.54$ & 0.94 \\
\hline BIII & 2 & $2.89 \pm 0.83$ & $1.18 \pm 0.34$ & $1.72 \pm 0.92$ & 0.62 \\
\hline $\mathrm{Cl}$ & 2 & $4.14 \pm 0.80$ & $2.98 \pm 0.58$ & $4.35 \pm 1.99$ & 0.61 \\
\hline CII & 2 & $4.34 \pm 0.91$ & $2.76 \pm 0.58$ & $4.80 \pm 2.15$ & 0.56 \\
\hline CIII & 2 & $6.17 \pm 1.52$ & $2.59 \pm 0.64$ & $3.36 \pm 1.08$ & 0.79 \\
\hline DI & 2 & $8.19 \pm 1.65$ & $5.85 \pm 1.18$ & $9.02 \pm 1.75$ & 0.65 \\
\hline DII & 2 & $5.99 \pm 1.82$ & $3.81 \pm 1.16$ & $6.92 \pm 1.12$ & 0.55 \\
\hline DIII & 2 & $10.28 \pm 1.20$ & $4.20 \pm 0.51$ & $6.92 \pm 1.41$ & 0.61 \\
\hline BI & 12 & $1.45 \pm 0.04$ & $1.08 \pm 0.03$ & $2.00 \pm 0.64$ & 0.54 \\
\hline BII & 12 & $1.46 \pm 0.16$ & $1.15 \pm 0.13$ & $1.59 \pm 0.11$ & 0.72 \\
\hline BIII & 12 & $1.47 \pm 0.42$ & $0.88 \pm 0.25$ & $2.06 \pm 0.25$ & 0.43 \\
\hline CI & 12 & $4.57 \pm 0.32$ & $3.41 \pm 0.24$ & $4.60 \pm 1.43$ & 0.74 \\
\hline CII & 12 & $4.14 \pm 0.40$ & $3.27 \pm 0.32$ & $4.12 \pm 1.06$ & 0.79 \\
\hline CIII & 12 & $4.93 \pm 0.67$ & $2.95 \pm 0.40$ & $3.64 \pm 1.01$ & 0.81 \\
\hline
\end{tabular}


et al.,1987) represent the 'acclimated' condition. A central purpose of the study was to establish whether aspects of the feeding behaviour differed between the acute and acclimated states.

\section{Physiological determinations}

Physiological determinations included rates of filtration by the mussels (the rate at which seston is filtered from suspension; $\mathrm{mg} \mathrm{h}^{-1}$ ), rates of biodeposition (the rate at which filtered material is egested and deposited as faeces and pseudofaeces; $\mathrm{mg} \mathrm{h}^{-1}$ ); selection efficiencies (the efficiency with which filtered material is sorted into organic and inorganic fractions prior to ingestion); ingestion rates (as $\mathrm{mg} \mathrm{h}^{-1}$ ); absorption efficiencies (the efficiency with which the organic fraction of ingested material is absorbed by the animal); gut content (the mass of ingested material held within the gut; $\mathrm{mg}$ ); and rates of oxygen consumption ( $\mathrm{ml}$ oxygen $\mathrm{h}^{-1}$ ). In addition, the gross biochemical composition (protein, lipid and carbohydrate) was determined for both seston and faeces.

On five occasions over $2 \mathrm{~d}$, samples of water flowing into and out of the experimental trays were collected in triplicate for analysis of seston content and composition. Particulate material in a fixed volume of water was filtered onto preweighed and ashed GFC filters, dried at $110^{\circ} \mathrm{C}$, weighed, then ashed at $450^{\circ} \mathrm{C}$ prior to final weighing. From these results we established total seston concentration (total dry mass of particulate material, $\mathrm{mg} \mathrm{l}^{-1}$ ) and the concentration of particulate organic matter (POM; from weight loss on ashing, $\mathrm{mg}^{-1}$ ), for both inflow and outflow samples. Knowing the rate of flow of water plus seston through the trays (as $1 \mathrm{~h}^{-1}$ ), filtration rates for each tray were then calculated as [inflow seston - outflow seston] $x$ flow rate, and divided by the numbers of animals in the tray $(\mathrm{N}=12)$ to derive an estimate of filtration rate ( $\mathrm{mg}$ total particulates per hour) per individual. (We distinguish between 'filtration rate' as defined above and 'clearance rate', which is the rate at which water pumped by the animal is cleared of particulate matter by filtration; clearance rates were not determined in this study.)

On each of two mornings, the biodeposits (i.e. faeces and pseudofaeces) were cleaned from the trays. By careful pipetting, five separate samples of faeces and pseudofaeces (where present, see below) were then collected, at intervals during the day, from each of three groups of four animals. This material was filtered onto preweighed and ashed GFC filters and dried and ashed, as described above, to determine the total mass and the organic content of the biodeposits. For conditions A and B, where seston concentrations were below the threshold for pseudofaeces production, these biodeposits comprised faeces only; for conditions $\mathrm{C}$ and $\mathrm{D}$, the biodeposits comprised both true faeces (i.e. material which had passed through the gut) and pseudofaeces (i.e. material filtered from suspension but rejected within the mantle cavity and not ingested). From these results, and knowing the rates of filtration, we calculated the proportion of material filtered (as total seston) that is rejected as pseudofaeces in conditions $C$ and D. Selection efficiency was then calculated as:

$$
\mathrm{SE}=100 \times[1-(\mathrm{P} / \mathrm{F})]
$$

where $P$ is the organic content of the pseudofaeces and $F$ is the organic content of the food. 
For conditions $\mathrm{A}$ and $\mathrm{B}$, rates of ingestion of organic matter were equivalent to rates of filtration ( $\left(\mathrm{FR}_{\mathrm{POM}}\right)$. For conditions $\mathrm{C}$ and $\mathrm{D}$, rates of ingestion of organic matter $\left(\mathrm{IR}_{\mathrm{POM}}\right)$ were estimated directly, from measurements of the proportion of pseudofaeces in the biodeposits and the organic content of the food, faeces and pseudofaeces.

Absorption efficiency was calculated by the ratio method of Conover (1966):

$$
\mathrm{AE}=(\mathrm{F}-\mathrm{E}) /(1-\mathrm{E}) \times \mathrm{F}
$$

where $\mathrm{F}$ is the organic content of the ingested food and $\mathrm{E}$ is the organic content of the (true) faeces. The rate of absorption of material from the ration ( $\mathrm{mg}$ POM $\mathrm{h}^{-1}$ ) is then calculated as ingestion rate $x$ absorption efficiency.

To determine gut fullness, each tray was cleaned of biodeposits and the animals immersed in water filtered at $1 \mu \mathrm{m}$. Faeces were then collected from each of three groups of mussels per tray (four mussels per group) at 1,3,24 and $48 \mathrm{~h}$, filtered, dried and weighed; the total mass of faeces collected represents the 'post absorptive gut contents'

$-\left(\mathrm{GC}_{\mathrm{post}}\right)$. To estimate the 'pre-absorptive gut contents' $\left(\mathrm{GC}_{\mathrm{pre}}\right)$, we used the following expression (Navarro et al., 1992):

$$
\left.\mathrm{GC}_{\mathrm{pre}}=\text { egested inorganics + [egested organics / }(1-\mathrm{AE})\right] \text {. }
$$

We have taken the average of $\mathrm{GC}_{\text {post }}$ and $\mathrm{GC}_{\text {pre }}$ to indicate mean gut content.

Faeces and pseudofaeces were collected on GFC filters as described above, dried and used for biochemical analysis, together with samples of each diet. Proteins were solubilized in double-distilled water and analysed according to Lowry et al. (1951). Total lipids were extracted with a mixture of chloroform and methanol (Bligh \& Dyer, 1959) and analysed following Marsh \& Weinstein (1966). Total carbohydrates were determined according to Dubois et al. (1956). Measurements of biochemical content were used to determine ingestion rates, absorption efficiencies and rates of absorption for each ration condition.

When samples for all of the above determinations had been taken from conditions $B$ and $C$ (at $2 \mathrm{~d}$ and $12 \mathrm{~d}$ ), mussels were removed from the experimental trays for measurements of rates of oxygen consumption. The mussels were placed individually in glass vessels containing $125 \mathrm{ml}$ of filtered and aerated sea-water. The vessels were sealed with a Radiometer ${ }^{\circledR}$ oxygen electrode and placed in a water bath $\left(15^{\circ} \mathrm{C}\right)$ standing upon

a base of magnetic stirrers, which activated small stirrer bars in each respirometer vessel (Bayne et al., 1987). The decline of dissolved oxygen within each vessel was monitored over $2 \mathrm{~h}$, and the rate of decline used to calculate the rate of oxygen consumption by the mussel; vessels without mussels were used as controls to correct for any oxygen uptake not attributed to the respiration of the animals.

At the end of the experiment the flesh was dissected from the shells and dried at $110^{\circ} \mathrm{C}$ for $48 \mathrm{~h}$ prior to weighing. All physiological determinations were then 'standardized' to a mean dry body mass of $300 \mathrm{mg}$ (which was close to the actual mean body mass of experimental animals; $320 \pm 45 \mathrm{SD} \mathrm{mg}$ ), using the following equation:

$$
\mathrm{Y}_{\mathrm{s}}=\mathrm{Y}_{\mathrm{e}} \times\left(300 / \mathrm{W}_{\mathrm{e}}\right)^{b}
$$

where $Y_{s}$ is the standardized physiological rate, $Y_{e}$ is the experimentally determined 
rate, $\mathrm{W}_{\mathrm{e}}$ is the measured dry body mass of the individual, and $b$ is the exponent in the allometric equation which relates each physiological trait to body mass. We have used the following values for $b$ : all measures of feeding rate, 0.67 (Bayne et al., 1989); all efficiencies, 0 (=independent of size); gut contents, 0.68 (Hawkins et al., 1990); oxygen consumption rate, 0.75 (Bayne et al., 1989).

\section{Statistical analysis}

The data were analysed according to the following protocol, having in mind that ration treatments were not replicated in the experimental design. Firstly, a two-way analysis of variance was carried out to determine the significance of observed differences in the mean values for the acute physiological responses due to the 'main effects' of seston quantity and organic content, using the interaction mean square as the denominator in the F-ratio. Where appropriate, regression analysis was then applied, both to determine the most appropriate model with which to describe relationships within the data and to illustrate significant features of the results. Regression analysis fitted a linear $(\mathrm{y}=a+b . \mathrm{x}$ and a multiplicative $\left(y=a . x^{b}\right)$ model to the relevant data set, compared the goodness-offit, and derived the parameter values $a$ and $b$ for the model with the highest $F$ value. Covariance analysis was used to compare regressions to determine the significance of differences between fitted values for $a$ and $b$. A paired $t$-test was used to compare values for the acute (day 2) and acclimated (day 12) states for ration conditions B and C.

\section{RESULTS}

\section{The ration conditions}

The concentrations of seston and POM are listed in Table 1. Mean total seston quantity (with $95 \%$ confidence limits) ranged from $1.29 \pm 0.20 \mathrm{mg} \mathrm{l}^{-1}$ at ration level A to $2.87 \pm 0.44$, $4.95 \pm 0.87$ and $8.14 \pm 1.25 \mathrm{mg} \mathrm{l}^{-1}$ for rations $\mathrm{B}, \mathrm{C}$ and $\mathrm{D}$, respectively (all at $2 \mathrm{~d}$ ); equivalent mean values for POM were $0.72 \pm 0.08,1.68 \pm 0.33,2.78 \pm 0.35$ and $4.62 \pm 0.68 \mathrm{mg} \mathrm{l}^{1-1}$. Both total seston and POM concentrations declined during $12 \mathrm{~d}$ for condition $\mathrm{B}$ (to $1.46 \pm 0.31$, $P<0.001$, and $1.04 \pm 0.22, P<0.001$, respectively) but remained unchanged for condition $C$ ( $4.55 \pm 0.64$ and $3.21 \pm 0.43$ for total seston and POM, respectively, at $12 \mathrm{~d}$ ).

When ration quality was calculated as $\mathrm{mg} \mathrm{POM} \mathrm{mm}^{-3}$ of total particulate volume, thero were no significant differences amongst all conditions, nor over time for conditions $B$ and $C$, with mean values of $0.68 \pm 0 \cdot 14$ at $2 \mathrm{~d}$ and $0.67 \pm 0.14$ at $12 \mathrm{~d}$.

\section{Physiological results}

Filtration rates $\left(\mathrm{mg} \mathrm{h}^{-1}\right)$ increased with increased seston concentration (Figure 1). Regression analysis supports a curvilinear rather than linear fit for this relationship; for ration conditions I and II pooled (experimental values similar), $F_{1,30}=76.8$ for the linear model and 166.3 for the multiplicative model; for ration condition III the equivalent values were $F_{1,14}=60.4$ and 128.0 for the linear and multiplicative models, respectively. Analysis of covariance also indicates that filtration rates on ration III were higher overall 


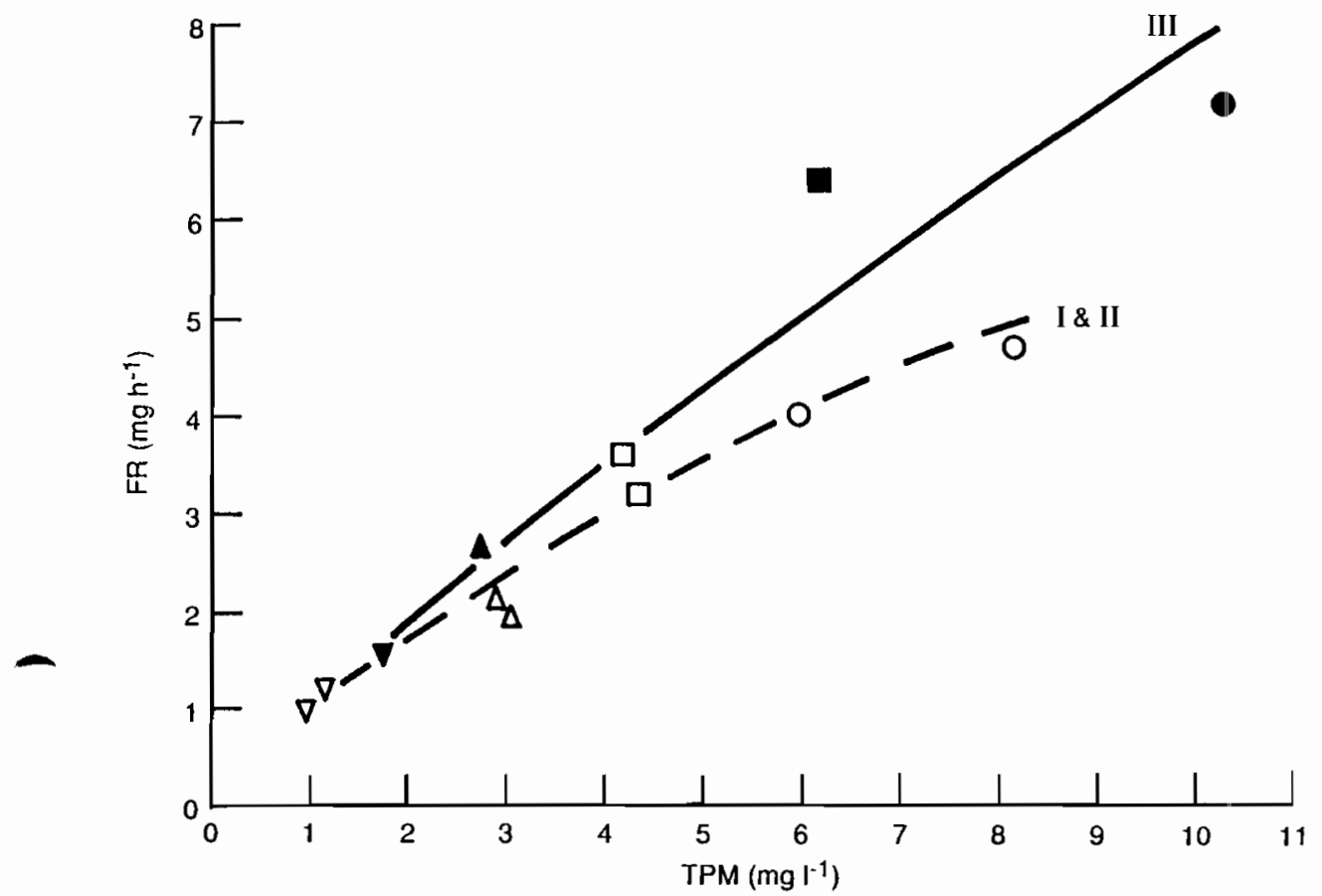

Figure 1. Rates of filtration (FR; $\mathrm{mg} \mathrm{h}^{-1}$ per $300 \mathrm{mg}$ dry tissue mass) as a function of total seston concentration (TPM; $\mathrm{mg}^{-1}$ ). Open symbols and the dashed line are for ration conditions I and II; closed symbols and the solid line for condition III. $\boldsymbol{\nabla}$, ration $\mathrm{A} ; \boldsymbol{\Delta}, \mathrm{B} ; \boldsymbol{\mathbf { G }}, \mathrm{C} ; \boldsymbol{\bullet}, \mathrm{D}$. The lines are fitted according to the following equations: for conditions I and II, FR=1.05( $\pm 0.93 \mathrm{SD}) . \mathrm{TPM}^{0.747( \pm 0.07)}\left(r^{2}=95 \%\right)$; for condition III, FR $=0.83( \pm 0 \cdot 17) . \mathrm{TPM}^{0.983( \pm 0 \cdot 17)}\left(r^{2}=94.5 \%\right)$.

than on rations I and II; the estimated slope of the former, as plotted in Figure 1, is 0.983 \pm 0.168 , compared with $0.747 \pm 0.070$ for ration conditions I and II pooled, a difference which is significant at $P<0 \cdot 01$. At high seston concentrations, then (which were above the pseudofaeces threshold), filtration rates were significantly higher at the ration of lowest organic content.

Filtration rates at ration $\mathrm{B}$ did not differ between the acute and acclimated conditions.

For ration $\mathrm{C}$, however, filtration rates increased between 2 and $12 \mathrm{~d}$; at similar seston levels ( $4.88 \pm 0.95$ and $4.54 \pm 0.34 \mathrm{mg} \mathrm{l}^{-1}$ for 2 and $12 \mathrm{~d}$, respectively), filtration rates were $3.79 \pm 1.12$ and $4.61 \pm 0.53 \mathrm{mg}$ seston $\mathrm{h}^{-1}$ for 2 and $12 \mathrm{~d}(t=4.93, P<0.01)$.

As the seston concentration increased, the proportion of filtered material which was rejected as pseudofaeces increased (Figure 2), from zero rejection at the pseudofaeces threshold of approximately $3 \mathrm{mg} \mathrm{l}^{-1}$, to $40 \%$ rejection of filtered ration of lowest organic content, at seston concentrations of $6-10 \mathrm{mg} \mathrm{l}^{-1}$. The results describe an asymptotic relationship which reaches higher maximum values for 'proportion rejected' at rations which are low in organic content (cf. I and III in Figure 2).

The proportion of filtered material which was rejected as pseudofaeces increased between 2 and $12 \mathrm{~d}$ (ration condition $\mathrm{C}$ ). This is best illustrated by reading off from the curves plotted in Figure 2 (i.e. day 2 values) 'percent rejections' for the same seston 


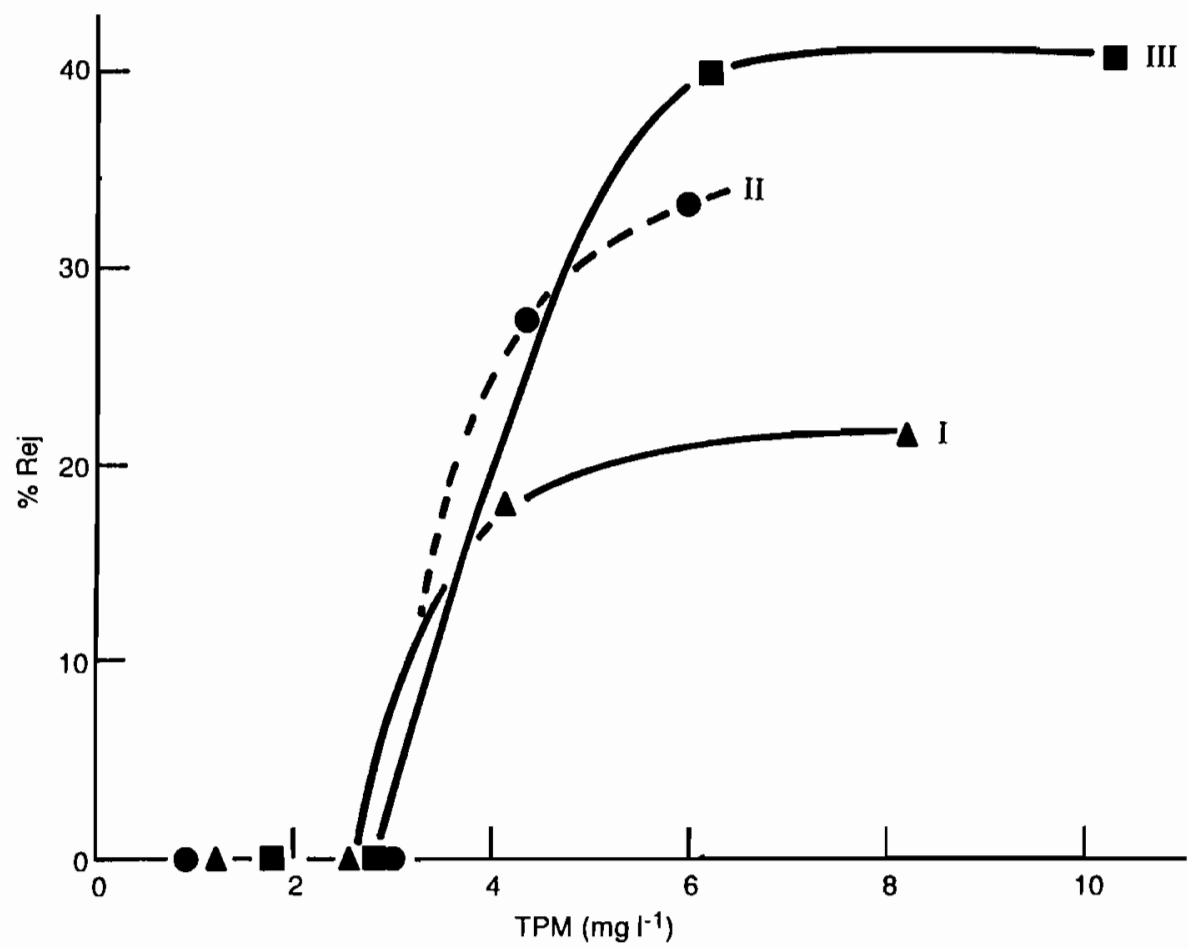

Figure 2. The percentage of filtered material rejected as pseudofaeces (\% Rej) as a function of total seston concentration (TPM; $\mathrm{mg} \mathrm{l}^{-1}$ ), at $2 \mathrm{~d}$. Lines have been drawn by eye separately for ration

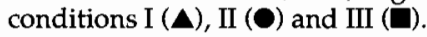

concentrations at which measurements were made at day 12 (Table 2). In addition to increased rejections over time, there is a suggestion that the increase was greater on diets of highest organic content (CI and II vs CIII).

Table 2. Comparison of interpolated (values from Figure 2) of percentage rejection at $2 d$ with measurements made at $12 d$.

$\begin{array}{cccc}\text { Condition } & \text { Seston concentration }\left(\mathrm{mg}^{-1}\right) & \text { \% rejection at } 2 \mathrm{~d} & \text { \% rejection at } 12 \mathrm{~d} \\ \mathrm{CI} & 4.57 & 19.3 & 49.6 \\ \mathrm{CII} & 4.14 & 25.2 & 48.9 \\ \mathrm{CIII} & 4.93 & 31.7 & 38.9\end{array}$

As the organic content of the seston increased, selection efficiency declined (Figure 3). The curve plotted in Figure 3 is fitted by eye to express a trend in SE that is not directly proportional to the organic content of the diet. Selection efficiency did not change significantly between 2 and $12 \mathrm{~d}$.

The rate of ingestion of organic matter (IR; $\mathrm{mg} \mathrm{POM} \mathrm{h}^{-1}$ ) increased with increased concentration of POM (Figure 4); IR was highest for ration conditions $\mathrm{C}$ and D and for 


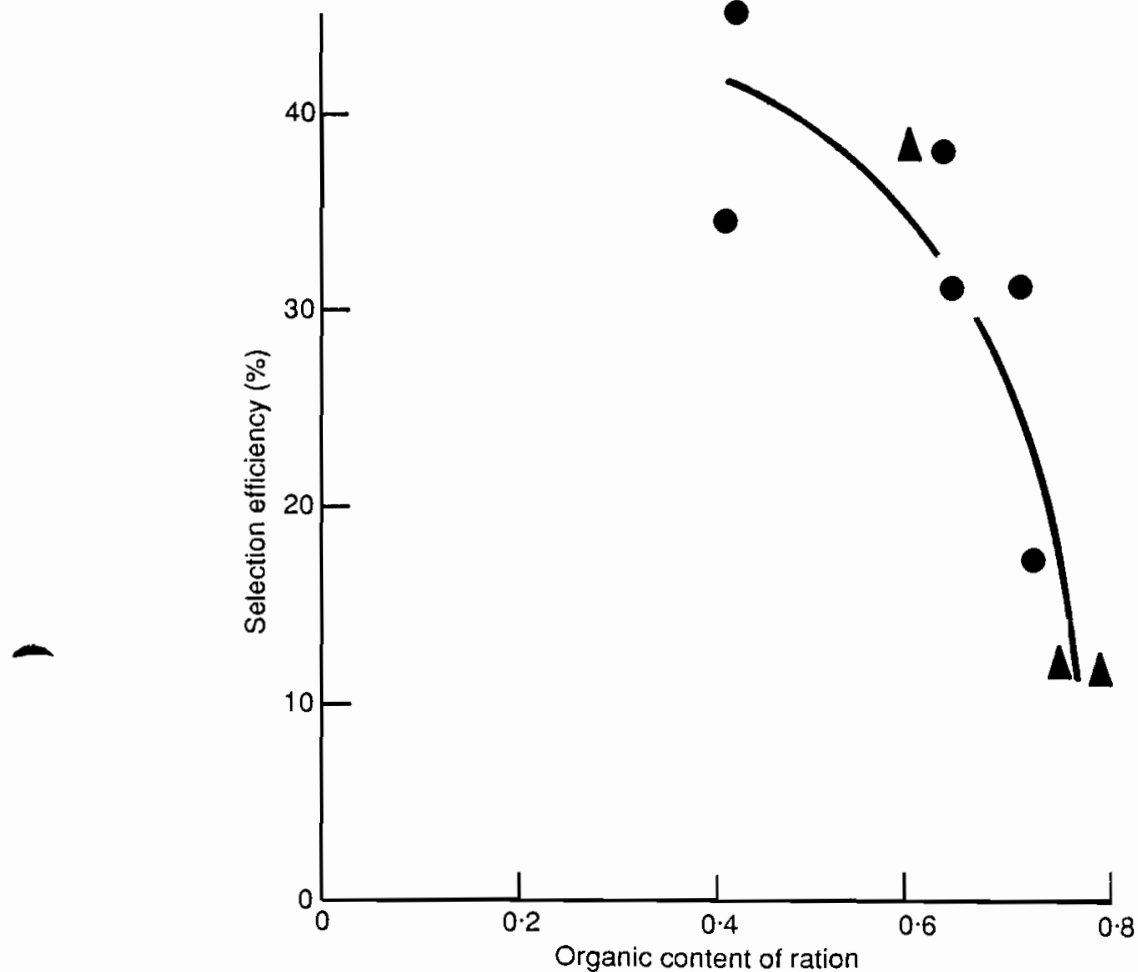

Figure 3. Selection efficiency (SE, \%) as a function of the proportional organic content of the ration. The line has been fitted by eye to data for both $2-d(\boldsymbol{\bullet}$, rations $C$ and $D)$ and $12-d(\boldsymbol{A}$, ration $C)$ exposures.

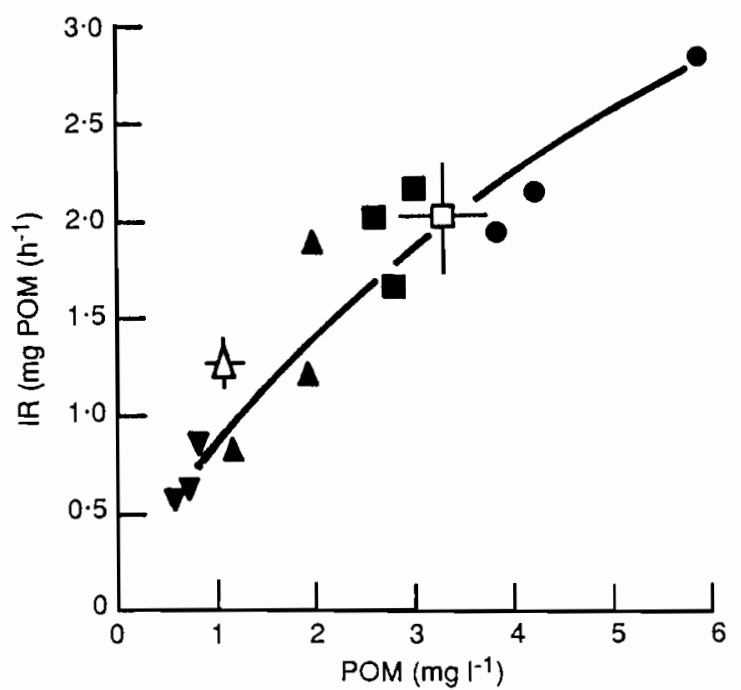

Figure 4. The rate of ingestion of organic matter (IR; $\left.\mathrm{mg} \mathrm{POM} \mathrm{h}^{-1}\right)$ as a function of the concentration of suspended organic matter (POM; $\mathrm{mg} \mathrm{l}^{-1}$ ). Closed symbols are for 2-d exposures, open symbols for the 12 -d exposures; the latter are means $\pm 95 \% \mathrm{CL}$. $\boldsymbol{\nabla}$, ration $\mathrm{A} ; \boldsymbol{A}, \mathrm{B} ; \mathbf{\square}, \mathrm{C} ; \boldsymbol{\nabla}, \mathrm{D}$. The line is fitted according to the equation (for 2-d values only): $I R=0.97( \pm 0.06) . P^{0} M^{0.609( \pm 0.07)}\left(r^{2}=83.4 \%\right)$. 
Table 3. Absorption efficiencies for each ration condition. Values are means with $95 \%$ confidence limits to express the variability between groups of individuals, for six determinations (four for condition $D$ ) of faeces pooled from five individuals. These are 'true' absorption efficiencies i.e. as determined on deposits of true faeces, excluding biodeposits of pseudofaeces in conditions $C \& D$.

$\begin{array}{cc}\text { Ration condition } & \text { Days } \\ \text { AI } & 2 \\ \text { AII } & 2 \\ \text { AIII } & 2 \\ \text { BI } & 2 \\ \text { BII } & 2 \\ \text { BII } & 2 \\ \text { CI } & 2 \\ \text { CII } & 2 \\ \text { CIII } & 2 \\ \text { DI } & 2 \\ \text { DII } & 2 \\ \text { DIII } & 2 \\ \text { BI } & 2 \\ \text { BII } & 12 \\ \text { BIII } & 12 \\ \text { CI } & 12 \\ \text { CII } & 12 \\ \text { CIII } & 12 \\ & 12\end{array}$

Absorption efficiency

$0.50 \pm 0.11$

$0.43 \pm 0.06$

$0.23 \pm 0.14$

$0.29 \pm 0.08$

$0.34 \pm 0.11$

$0.35 \pm 0.07$

$0.40 \pm 0.19$

$0.60 \pm 0.13$

$0.28 \pm 0.11$

$0.50 \pm 0.23$

$0.55 \pm 0.11$

$0.42 \pm 0.13$

$0.45 \pm 0.08$

$0.48 \pm 0.04$

$0.58 \pm 0.08$

$0.46 \pm 0.14$

$0.48 \pm 0.16$

$0.58 \pm 0.11$

ration of greatest organic content (i.e. condition I). The appropriate form of this relationship was curvilinear: $F_{1,46}=84.1$ and 176.8 for the linear and multiplicative models, respectively. There was no significant difference in $I R$ at 2 and $12 \mathrm{~d}$ for conditions $B$ and $C$. The results indicate that the increased FR for condition $C$ from $2 \mathrm{~d}$ to $12 \mathrm{~d}$ did not result in an increased IR ( $c f$. open and closed squares in Figure 4) because it was countered by an increased proportional rejection of pseudofaeces with no change in selection efficiency.

There were no consistent differences within the data for absorption efficiency between ration conditions at $2 \mathrm{~d}$ (Table 3 ). The overall mean $\mathrm{AE}$ at $2 \mathrm{~d}$ (all conditions, $\mathrm{N}=12$ ) was $0.40 \pm 0.12$, and the mean for conditions $B$ and $C$ only $(N=6)$ was $0.38 \pm 0.11$. After $12 d$, however, there was a significant increase in absorption efficiency for conditions $B$ and $C$ combined; $\mathrm{AE}=0.50 \pm 0.05(t=4.30 ; P<0.01)$.

The rate of absorption of organics from the ingested ration ( $A R ;{\mathrm{mg} P O M \mathrm{~h}^{-1}}^{-1}$ increased with increase in the concentration of POM (Figure 5). For these data both the linear and the multiplicative models gave equally good fits: $F_{1,46}=126 \cdot 3$ and $131 \cdot 9$, respectively. We have adopted the linear model fit in Figure 5. After $12 \mathrm{~d}, \mathrm{AR}$ in ration conditions $\mathrm{B}$ and $\mathrm{C}$ had increased significantly. Analysis of covariance of the data in Figure 5 indicates that the slopes of the two relationships (for 2 and $12 \mathrm{~d}$ ) were not significantly different, but the elevations were $\left(\mathrm{F}_{1,69}=22.9 ; P<0.001\right)$.

As expected, gut contents increased with increased seston concentration and increased IR (data not shown). However, there were no significant differences in total gut content between rations of similar quantity but differing in organic content (i.e. ration I, II and III), nor over time (for rations $B$ and $C$ at 2 and $12 \mathrm{~d}$ ). 


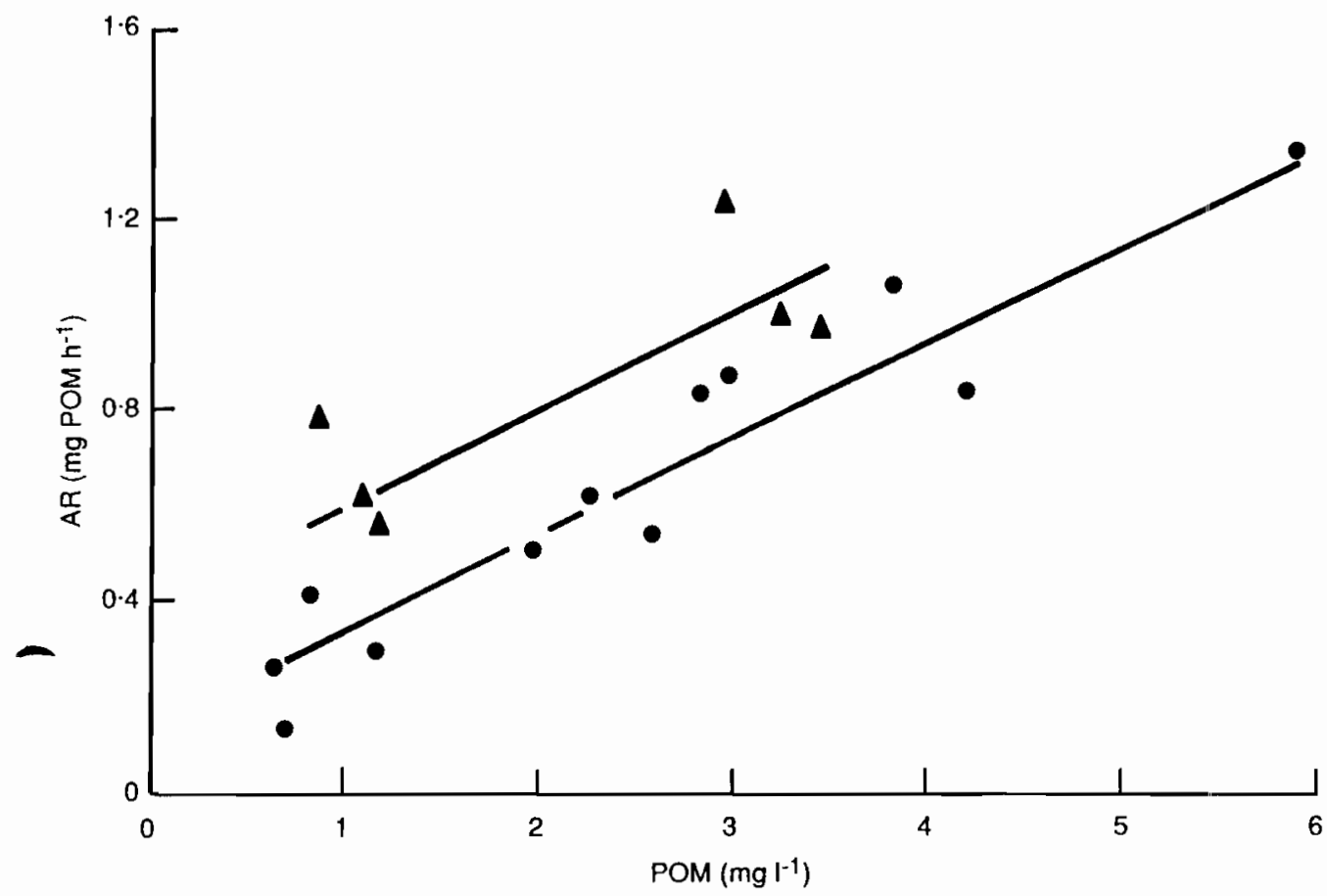

Figure 5. The rate of absorption of organic matter (AR; $m g$ POM $\mathrm{h}^{-1}$ ) as a function of the concentration of suspended organic matter ( $\mathrm{POM} ; \mathrm{mg} \mathrm{l}^{-1}$ ) for $2-\mathrm{d}(\boldsymbol{O})$ and $12-\mathrm{d}(\boldsymbol{\Delta})$ exposures. Parallel lines have been fitted following covariance analysis, as follows: for 2-d exposures, $A R=0 \cdot 14( \pm 0 \cdot 11)+0 \cdot 202( \pm 0 \cdot 04)$. POM $\left(r^{2}=92 \%\right)$; for 12-d exposures, $\mathrm{AR}=0 \cdot 40( \pm 0 \cdot 12)+0 \cdot 202( \pm 0 \cdot 04)$.POM $\left(r^{2}=87 \cdot 4 \%\right)$. These two lines are significantly different in elevation $\left(F_{1,69}=22.9 ; P<0.001\right)$.

Rates of oxygen consumption are presented in Table 4 . There were no significant differences in oxygen consumption between ration conditions (measured for B and C, I, II and III, only), nor over time (days 2 and 12).

Table 4. Rates of oxygen consumption at ration conditions B and C. Values are means and $95 \%$ confidence limits which express the variability between individuals $(N=10)$. Measured rates ave been standardized to a tissue dry mass of $300 \mathrm{mg}$.

$\begin{array}{cc}\text { Ration condition } & \text { Days } \\ \text { BI } & 2 \\ \text { BII } & 2 \\ \text { BIII } & 2 \\ \text { CI } & 2 \\ \text { CII } & 2 \\ \text { CIII } & 2 \\ \text { BI } & 12 \\ \text { BII } & 12 \\ \text { BIII } & 12 \\ \text { CI } & 12 \\ \text { CII } & 12 \\ \text { CIII } & 12\end{array}$

Oxygen consumption: $\left(\mathrm{ml} \mathrm{O}_{2} \mathrm{~h}^{-1}\right)$
$0.167 \pm 0.027$
$0.182 \pm 0.051$
$0.154 \pm 0.030$
$0.186 \pm 0.043$
$0.207 \pm 0.039$
$0.215 \pm 0.058$
$0.163 \pm 0.049$
$0.181 \pm 0.051$
$0.230 \pm 0.060$
$0.191 \pm 0.042$
$0.178 \pm 0.040$
$0.187 \pm 0.032$ 


\section{Biochemical results}

Average absorption efficiencies as determined for different biochemical components of the food and faeces (protein, lipid and carbohydrate) are listed in Table 5. The rank order for AE across pooled values for each component (following paired $t$-tests) was carbohydrate $>$ lipid $>$ protein. There were no significant differences in AE for changes in

Table 5. Absorption efficiencies for biochemical components of the diet, at ration conditions $B$ and $C$ and as measured at 2 and $12 \mathrm{~d}$. Values are means with 95\% confidence limits, for measurements on three groups of animals for each condition and with values pooled across three levels of organic content ( $N=9$ for each component).

$\begin{array}{cccc}\text { Biochemical component } & \text { Diet condition } & \text { Time (d) } & \text { Absorption efficiency } \\ \text { Lipid } & \text { B } & 2 & 0.33 \pm 0.07 \\ & \text { B } & 12 & 0.47 \pm 0.07 \\ \text { Protein } & \text { C } & 2 & 0.35 \pm 0.12 \\ & \text { C } & 12 & 0.33 \pm 0.09 \\ \text { Carbohydrate } & \text { B } & 2 & 0.26 \pm 0.10 \\ & \text { B } & 12 & 0.50 \pm 0.08 \\ & \text { C } & 2 & 0.29 \pm 0.12 \\ & \text { C } & 12 & 0.23 \pm 0.11 \\ & \text { B } & 2 & 0.36 \pm 0.03 \\ & \text { B } & 12 & 0.53 \pm 0.03 \\ & \text { C } & 2 & 0.34 \pm 0.05 \\ & \text { C } & 12 & 0.44 \pm 0.03\end{array}$

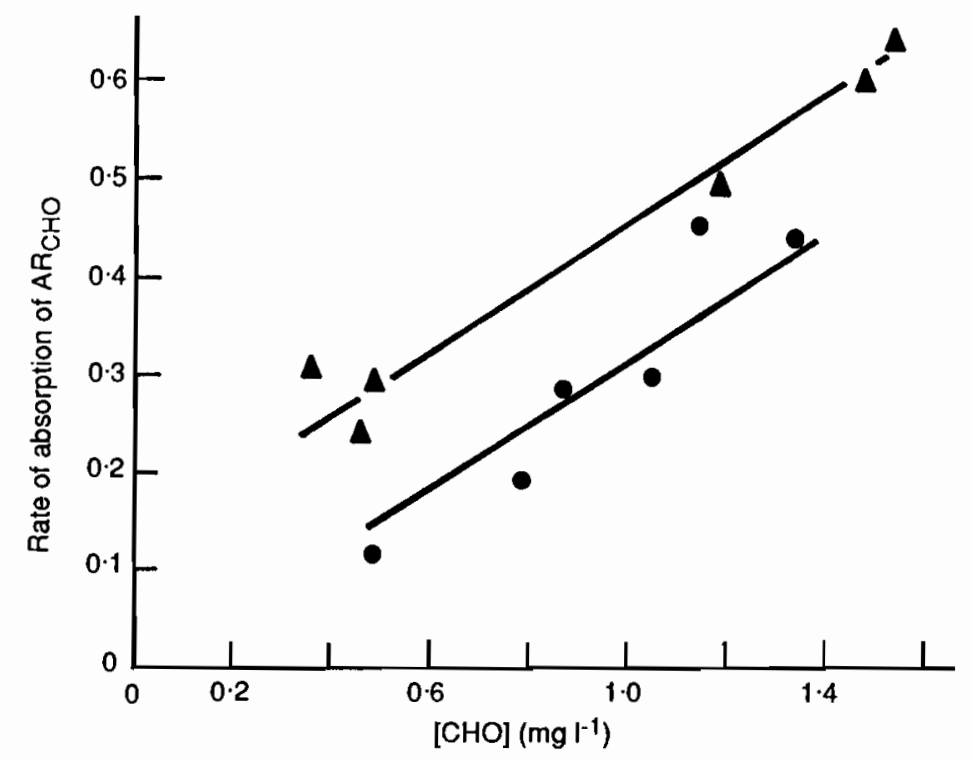

Figure 6. Rates of absorption of carbohydrates $\left(\mathrm{mg} \mathrm{h}^{-1}\right)$ as a function of the concentration of carbohydrates within the suspended particulates $\left(\mathrm{mg} \mathrm{l}^{-1}\right)$. $\mathbf{0}, 2$ - $\mathrm{d}$ exposures; $\boldsymbol{\Delta}, 12-\mathrm{d}$ exposures. Covariance analysis identified a significant difference in elevation $\left(\mathrm{F}_{1 \mathrm{~g}}=20.15 ; P<0.005\right)$ but no difference in slopes. The regression lines as plotted were: for $2 \mathrm{~d}, \mathrm{AR}_{\mathrm{CHO}}=0.32( \pm 0.13)$. [CHO]-0.008( \pm 0.009$)\left(r^{2}=84.2 \%\right)$; for $12 \mathrm{~d} . \mathrm{AR}_{\text {Сно }}=0 \cdot 32( \pm 0 \cdot 13) \cdot[\mathrm{CHO}]+0 \cdot 125( \pm 0 \cdot 08)\left(r^{2}=92 \cdot 3 \%\right)$. 
diet quantity or organic content. Between 2 and $12 \mathrm{~d}$ AE for carbohydrates increased (Figure 6), but values for lipids or proteins did not alter significantly with time. Multiple regression analysis indicates that the regression slopes in Figure 6 were not significantly different, but the elevations were $\left(\mathrm{F}_{1,9}=20 \cdot 15 ; P<0.005\right)$.

\section{DISCUSSION}

One aim of these experiments was to determine whether there are features in the feeding behaviour of mussels which result in an enhanced ingestion rate of particulate organic matter in circumstances where the ration available comprises seston of low organic content. There are three behavioural responses that might act together to increase the ingestion rate of organics above an expectation based simply on the organic/ inorganic ratio of the available particles, viz an increase in the rate at which material is filtered from suspension, a change in the proportion of this material that is rejected as sseudofaeces (i.e. that is not ingested) and an increase in the efficiency with which organic material is selected from the particles filtered for ingestion.

All three potential mechanisms were observed in mussels feeding on the ration condition III (i.e. seston which averaged $40.8 \%$ organic matter), compared with ration condition I, which averaged $71.9 \%$ organic content. At the lower organic content rates of filtration were increased, the proportion of filtered material rejected also increased, and concomitant with this rejection there was an increase in the efficiency with which organic material was selected for ingestion. By comparing the observed rates of ingestion of organics with a theoretical expectation based on no changes in feeding between high and low organic content rations, we estimate an average increase, over the null expectation, of $35 \%$ in $\mathrm{IR}_{\mathrm{POM}}$, as a result of these behavioural changes. This increase is similar in magnitude to that recorded by Iglesias et al. (1992) for Cerastoderma edule (L.) feeding on diets of different organic content. The net result is to compensate for the 'dilution' of organic material in the seston, rendering ingestion rates for organics that are a function only of POM availability, and not of the organic/inorganic ratio (Figure 4; see also Bayne et al., 1989).

The cellular mechanisms that underpin these physiological changes are not fully - resolved, although they will all involve processes of filtration, selection and rejection on che ctenidia and the labial palps. Nevertheless, it seems clear that some form of physiological compensation is involved, which effects a relative increase in the ingestion of organic matter and is dependent on dietary composition.

In the present study absorption efficiencies did not differ significantly amongst the ration conditions (at $2 \mathrm{~d}$ ), in apparent contradiction of earlier results (Bayne et al., 1987; Navarro et al., 1991) which demonstrated a positive correlation between absorption efficiency and estimates of food quality. However, in the present experiments food quality as measured in volumetric units $\left(\mathrm{mg} \mathrm{POM} \mathrm{mm}^{-3}\right)$ did not vary consistently across the experimental diets, and in such circumstances variation in $\mathrm{AE}$ is not to be expected, since our earlier experiments had demonstrated that variability in AE correlated with food quality in volumetric units, rather than organic content per se. 
Another apparent anomaly in these experiments concerns the rank order of absorption efficiencies for biochemical components of the diet. In previous experiments (Hawkins \& Bayne, 1985) we have recorded higher AEs for nitrogen than for carbon, predicting higher efficiencies for protein than for carbohydrate or lipid. The reverse occurred in these experiments, suggesting that $\mathrm{AE}$ may be sensitive to the balance of biochemical components in the diet. In earlier experiments the diets comprised phytoplankton cells only, with a $\mathrm{C}: \mathrm{N}$ ratio of approximately 6 or 7 . In the present experiments the organic matter comprised not only phytoplankton but also the organic content of the silt, and the $\mathrm{C}: \mathrm{N}$ ratio was $>13$. Further research is needed to resolve the relationship between biochemical composition of the diet and absorption efficiencies.

A second and related objective of these experiments was to evaluate an earlier hypothesis (Bayne et al., 1987) that postulated the acclimation of aspects of feeding behaviour by mussels held on organically poor diets (i.e. mixed silt and phytoplankton), which result in an increase over time in the net absorption of organic material. We compared mussels held for 2 and $12 \mathrm{~d}$ on two seston concentrations, one below (conditior B) and one above (condition C) the pseudofaeces threshold, each at three levels of organic content.

At both seston concentrations there was an increase between 2 and $12 \mathrm{~d}$ in the net rate of absorption of organics, confirming that acclimation did occur. At the lower food concentration, of the physiological traits measured only the absorption efficiency for organics increased during the acclimation period and this alone accounted for the increase in the rate of absorption (AR). At the higher seston concentration, we measured increases in the rateof filtration and in the proportion of material rejected as pseudofaeces, as well as significant increases in absorption efficiency. There was no increase in selection efficiency concomitant with increased pseudofaeces production (cf. the 'acute' response to the organically poor diet, discussed above), but the net result of the changes observed was nevertheless a significant increase in AR. To the extent that different absorption efficiencies may reflect different levels of digestive enzyme activities (J.F. Samain, personal communication, 1992), our results suggest that Mytilus requires between 2 and $12 \mathrm{~d}$ for the digestive enzymes to respond to changes in diet typical of our ration conditions $B$ and $C$.

Our results for both the 'acute' and 'acclimated' conditions are consistent with expectations derived from an optimality model for suspension feeders by Willows (1992). Under conditions of a 'broad spectrum of particles of varying quality' (loc. cit. p. 846), this model suggests that increased filtration rate combined with the rejection of lower quality particles, is the 'cost-efficient strategy' for maximizing net energy gain. In addition, the model postulates an increase in 'effective gut capacity', brought about through an increased rate of digestion increasing the gut space available for ingesta (and evidenced as an increase in absorption efficiency), as a further mechanism for increasing rate of absorption. In the absence of data on rates of acclimation, this model assumes instantaneous physiological responses to a change in ration. Present results and the results of our earlier experiments suggest that changes effecting increased absorption efficiency occur over a period of some days, whereas changes in filtration rate and in the rejection of filtered particles as pseudofaeces can, indeed, occur over much shorter time scales. 
The primary mechanism that effects acclimation of the rate of absorption of organics appears to be an enhanced absorption efficiency. This conclusion is reflected not only in absorption of total organics, but also in the results of absorption of carbohydrates. This in turn strongly implies a key role for the production of digestive enzymes. Total mass of gut contents did not change during acclimation. As Willows (1992) has suggested, an increased rate of digestion, brought about by an increased 'investment' in digestive enzymes, will enhance the rate of absorption both directly and indirectly; direct effects include increased rates of enzymatic breakdown of ingesta; indirect effects include the creation of more space within the digestive system for ingested material. The differential production of digestive enzymes in response to changes of diet has been reported for bivalves by Brock (1989) and Fielding (1987), and could constitute one mechanism for acclimation of the processes of digestion and absorption.

Rates of oxygen consumption did not change between the 2 and $12 \mathrm{~d}$ of acclimation of feeding and digestion processes. In such circumstances (i.e. no increases in rates of energy

oss), an increase in the rate of absorption of energy will constitute an increased capacity for growth. It is this increase in the net scope for growth that represents the eventual benefit to the organism, which may be maximized as a result of optimizing amongst component processes of feeding and energy balance (Willows, 1992).

In our earlier experiments in which acclimation to a change of diet was measured (Bayne $e$ t al., 1987), a reduction in rates of oxygen consumption occurred over time and contributed to the observed increase in scope for growth; this reduction was equated with the relatively low quantity of food available during the experiments. In the present case, food concentrations were maintained at higher values than in the earlier experi-

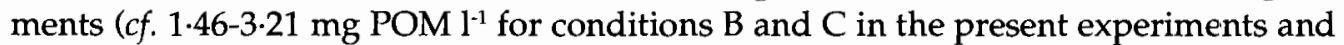
$0.25-0.30 \mathrm{mg} \mathrm{POM} \mathrm{I}^{-1}$ in the earlier study), and in these circumstances rates of oxygen consumption are expected to be maintained at higher values (Bayne \& Newell, 1983).

In summary, we have measured changes in the feeding physiology of mussels in response to diets which are low in organic content, and over time. These responses are 'compensatory' in nature since they lead to a relative enhancement of net energy and nutrient acquisition above the values which may be predicted from patterns of behaviour on diets of higher organic content, or from patterns of acute response to changes in diet.

Homoeostatic processes of this kind in the nutrient dynamics of an organism should come as no surprise, and provide evidence to counter the view that mussels and other suspension feeders are mere physiological slaves of the environment (Jørgensen, 1990).

We are grateful to our colleagues Mandy Day, Jean-François Samain and Jeanne Moal for participating with us in these experiments, and to Bob Clarke for statistical advice. Sandy Shumway and two anonymous referees made valuable comments on the manuscript.

\section{REFERENCES}

Bayne, B.L., Hawkins, A.J.S. \& Navarro, E., 1987. Feeding and digestion by the mussel Mytilus edulis L. (Bivalvia: Mollusca) in mixtures of silt and algal cells at low concentrations. Journal of Experimental Marine Biology and Ecology, 111, 1-22. 
Bayne, B.L.,Hawkins, A.J.S. \& Navarro, E., 1988. Feeding and digestion in suspension-feeding bivalve molluscs: the relevance of physiological compensations. American Zoologist, 28, 147-159.

Bayne, B.L., Hawkins, A.J.S., Navarro, E. \& Iglesias, J.I.P., 1989. Effects of seston concentration on feeding, digestion and growth in the mussel Mytilus edulis. Marine Ecology Progress Series, 55, 47-54.

Bayne, B.L. \& Newell, R.C., 1983. Physiological energetics of marine molluscs. In The Mollusca, vol. 4. Physiology, part 1 (ed. A.S.M. Saleuddin and K.M. Wilbur), pp. 407-515. New York: Academic Press.

Bligh, E.G. \& Dyer, W.J., 1959. A rapid method of total lipid extraction and purification. Canadian Journal of Biochemistry and Physiology, 37, 911-917.

Bricelj, V.M. \& Malouf, R.E., 1984. Influence of algal and suspended sediment concentrations on the feeding physiology of the hard clam Mercenaria mercenaria. Marine Biology, 84, 155-165.

Brock, V., 1989. Crassostrea gigas (Thunberg) hepatopancreas: cellulase kinetics and cellulolysis of living monocellular algae with cellulose walls. Journal of Experimental Marine Biology and Ecology, 128, 157-164.

Conover, R.J., 1966. Factors affecting the assimilation of organic matter by zooplankton and the question of superfluous feeding. Limnology and Oceanography, 11, 346-354.

Dubois, M.K., Gillis, A., Hamilton, J.K., Rebens, P.A. \& Smith, F., 1956. A colorimetric method for the determination of sugars and related substances. Analytical Chemistry, 28, 350-356.

Fielding, P.J., 1987. Relation of crystalline style function to food availability and environmental conditions in South African mussels. PhD thesis, University of Cape Town, South Africa.

Fielding, P.J. \& Davis, C.L., 1989. Carbon and nitrogen resources available to kelp bed filter feeders in an upwelling environment. Marine Ecology Progress Series, 55, 181-189.

Griffiths, C.L. \& Griffiths, R.J., 1987. Bivalvia. In Animal energetics (ed. T.J. Pandian and F.J. Vernberg), pp. 1-88. New York: Academic Press.

Hawkins, A.J.S. \& Bayne, B.L., 1985. Seasonal variation in the relative utilization of carbon and nitrogen by the mussel Mytilus edulis: budgets, conversion efficiencies and maintenance requirements. Marine Ecology Progress Series, 25, 181-188.

Hawkins, A.J.S. \& Bayne, B.L., 1992. Physiological interrelations, and the regulation of production. In The mussel Mytilus: ecology, physiology, genetics and culture (ed. E. Gosling), pp. 171-222. Amsterdam: Elsevier Science Publishers.

Hawkins, A.J.S., Navarro, E. \& Iglesias, J.I.P., 1990. Comparative allometries of gut passage time, gut content and metabolic faecal loss in Mytilus edulis and Cerastoderma edule. Marine Biology, 105, 197-204.

Iglesias, J.I.P., Navarro, E., Alvarez Jorna, P. \& Armentia, I., 1992. Feeding, particle selection and absorption in cockles Cerastoderma edule (L.) exposed to variable conditions of food concentration and quality. Journal of Experimental Marine Biology and Ecology, 162, 177-198.

Jørgensen, C.B., 1990. Bivalve filter feeding: hydrodynamics, bioenergetics, physiology and ecology. Fredensborg: Olsen and Olsen.

Jørgensen, C.B., Larsen, P.S., Møhlenberg, F. \& Riisgård, H.U., 1988. The mussel pump: properties and modelling. Marine Ecology Progress Series, 45, 205-216.

Kiørboe, T. \& Møhlenberg, F., 1981. Particle selection in suspension-feeding bivalves. Marine Ecology Progress Series, 5, 291-296.

Lowry, O.H., Rosebrough, N.J., Farr, A.L. \& Randall, R.J., 1951. Protein measurement with the folin phenol reagent. Joumal of Biological Chemistry, 193, 265-275.

Lucas, M.I., Newell, R.C., Shumway, S.E., Seiderer, L.J. \& Bally, R., 1987. Particle clearance and yield in relation to bacterioplankton and suspended particulate availability in estuarine and open coast populations of the mussel Mytilus edulis. Marine Ecology Progress Series, 36, 215-224.

Marsh, J.B. \& Weinstein, D.B., 1966. Simple charring method for determination of lipids. Journal of Lipid Research, 7, 574-576.

Navarro, E., Iglesias, J.I.P. \& Ortega, M.M., 1992. Natural sediment as a food source for the cockle Cerastoderma edule (L.): effect of variable particle concentration on feeding, digestion and the scope for growth. Journal of Experimental Marine Biology and Ecology, 156, 69-87.

Navarro, E., Iglesias, J.I.P., Perez Camacho, A., Labarta, U. \& Berias, R., 1991. The physiological 
energetics of mussels (Mytilus galloprovincialis Lmk.) from different cultivation rafts in the Ría de Arosa (Galicia, N.W. Spain). Aquaculture, 94, 197-212.

Newell, C.R., Shumway, S.E., Cucci, T.L. \& Selvin, R., 1989. The effects of natural seston particle size and type on feeding rates, feeding selectivity and food resource availability for the mussel Mytilus edulis Linnaeus, 1758 at bottom culture sites in Maine. Journal of Shellfish Research, 8, 187196.

Newell, R.I.E. \& Jordan, S.J., 1983. Preferential ingestion of organic material by the American oyster Crassostrea virginica. Marine Ecology Progress Series, 13, 47-53.

Shumway, S.E., Cucci, T.L., Newell, R.C. \& Yentsch, C.M., 1985. Particle selection, ingestion and absorption in filter-feeding bivalves. Journal of Experimental Marine Biology and Ecology, 91, 7792.

Stenton-Dozey, J.M.E. \& Brown, A.C., 1992. Clearance and retention efficiency of natural suspended particles by the rock-pool bivalve Venerupis corrugatus in relation to tidal availability. Marine Ecology Progress Series, 82, 175-186.

Widdows, I., Fieth, P. \& Worrall, C.M., 1979. Relationships between seston, available food and feeding activity in the common mussel Mytilus edulis. Marine Biology, 50, 195-207.

Willows, R.I., 1992. Optimal digestive investment: a model for filter feeders experiencing variable diets. Limnology and Oceanography, 37, 829-847.

Submitted 21 September 1992. Accepted 7 September 1993. 


$$
\omega
$$

$$
-
$$

